\title{
Gastrointestinal Motility Disorders: An Update
}

\author{
Brian E. Lacy Kirsten Weiser \\ Division of Gastroenterology and Hepatology, Dartmouth-Hitchcock Medical Center, Lebanon, N.H., USA
}

\section{Key Words \\ Motility disorders · Achalasia - Dyspepsia · \\ Gastroparesis · Constipation · Irritable bowel \\ syndrome $\cdot$ Chronic intestinal pseudo-obstruction}

\begin{abstract}
Gastrointestinal motility disorders encompass a wide array of signs and symptoms that can occur anywhere throughout the luminal gastrointestinal tract. Motility disorders are often chronic in nature and dramatically affect patients' quality of life. These prevalent disorders cause a tremendous impact both to the individual patient and to society as a whole. Significant progress has been made over the last 5 years in understanding the etiology and pathophysiology of gastrointestinal motility disorders. This clinical update will focus on seven of the most common gastrointestinal motility disorders (achalasia, non-achalasia esophageal motility disorders, dyspepsia, gastroparesis, chronic intestinal pseudo-obstruction, irritable bowel syndrome, and chronic constipation) with an emphasis on current treatment options and new therapeutic modalities.
\end{abstract}

Copyright $(2006$ S. Karger AG, Basel

\section{Introduction}

Gastrointestinal (GI) motility disorders are highly prevalent, produce an extensive array of symptoms, and occur anywhere throughout the lumen of the GI tract.
Patients with motility disorders have a reduced quality of life [1-4]. As well, these disorders impose a significant economic burden to both the individual patient and to society as a whole [5-7]. In this section of the journal, we will provide a summary of advances in the field of GI motility disorders over the last 5 years, with an emphasis on advances in treatment.

\section{Methods}

Ovid MEDLINE and PubMed databases were used to search the published literature. In the interest of providing an update, rather than providing a comprehensive review, our search was limited to the last 6 years. For Ovid MEDLINE (2000 to September 2005, English language only) 14 primary search terms (achalasia, esophagus, esophageal motility disorders, esophageal dysmotility, stomach, dyspepsia, gastroparesis, small intestine, chronic intestinal pseudoobstruction, colon, irritable bowel syndrome, constipation, motility disorders, diarrhea) were individually combined with a larger number of secondary search terms, including but not limited to (in alphabetical order): ABT229, alosetron, alternative medicine, alvimopan, antibiotics, biofeedback, botulinum toxin, buspirone, cilansetron, cisapride, complementary medicine, domperidone, erythromycin, gastric pacing, gastric stimulation, GM-611, itopride, levosulpiride, lubiprostone, medications, metoclopramide, mosapride, motilin, neostigmine, neurokinin, octreotide, pelvic floor, prucalopride, renzapride, sildenafil, suma-

\section{KARGER}

Fax +4161306 1234 E-Mail karger@karger.ch www.karger.com 
triptan, surgery, tachykinins, technology, tegaserod, therapies, treatment, tricyclic antidepressants. A similar search process was followed for PubMed (2000 to September 2005). All identified articles were then manually searched for other relevant studies. Abstracts were generally not included, except in limited circumstances.

\section{Achalasia}

Achalasia is the classic motility disorder of the esophagus. The annual incidence of achalasia is estimated at $1 / 100,000$ persons [8]. Clinically, achalasia is characterized by dysphagia, chest pain, and bland regurgitation. Manometrically, achalasia is defined by incomplete relaxation of the lower esophageal sphincter (LES) in combination with aperistalsis of the body of the esophagus. Pathophysiologically, achalasia develops as a result of denervation of the intrinsic nervous system of the esophagus, with loss of nitric-oxide containing neurons [9].

Current treatment options for achalasia include pneumatic dilation, surgery, or botulinum toxin injection (BTX). Although all three treatments can improve symptoms, none of these treatments restore esophageal peristalsis or normalize LES function. In the last 5 years, new data has emerged regarding methods to assess esophageal emptying, the efficacy and long-term outcome of standard treatments, and the use of new treatments.

The timed barium swallow (or timed barium esophagram) provides objective evidence of esophageal emptying [10]. Patients drink as much barium sulfate as they can over a 30- to 45-second period. Upright radiographs are taken 1,2, and $5 \mathrm{~min}$ after the last swallow of barium. The distance from the gastroesophageal junction to the top of the barium column is then measured, along with the width of the esophagus at the widest point. This study is repeated after treatment and compared to baseline. This test provides an objective measure of therapeutic response, in contrast to a subjective response based on symptom scores.

A recent study evaluated the long-term results of pneumatic dilation in 249 patients with achalasia [11]. 125 patients completed the questionnaire (58\%), with an average follow-up of 12 years. A median of 4 dilations was required, and the long-term success rate was estimated at only $40-50 \%$. These interesting results are in contrast to earlier studies (see below), and may indicate the need for earlier surgical referral. For example, Katz et al. [12] reported that after a mean follow-up of 6.5 years, $85 \%$ of their patients noted an improvement in symptoms after pneumatic dilation. A recent analysis of 232 achalasia patients treated at the Cleveland Clinic found that $86 \%$ of 111 patients had symptomatic improvement after pneumatic dilation [13]. Heller myotomy led to symptomatic improvement in $89 \%$ of 72 patients, while BTX injection of the LES improved symptoms in only $57 \%$ of patients, with benefits lasting 6 months on average.

Sildenafil, a phosphodiesterase- 5 inhibitor, is a potent smooth muscle relaxant. In normal volunteers, sildenafil reduces LES resting pressure and the amplitude of contractions in the distal esophagus [14, 15]. Similar findings were reported in two studies of patients with achalasia using $50 \mathrm{mg}$ of sildenafil $[15,16]$.

\section{Non-Achalasia Esophageal Motility Disorders}

The primary esophageal motility disorders include diffuse esophageal spasm (DES), nutcracker esophagus (NE), isolated hypertensive LES, idiopathic hypotensive LES, and ineffective esophageal motility (IEM) [17]. As a group, these disorders are associated with a number of non-specific symptoms, which include chest pain, dysphagia, and heartburn symptoms. Pathophysiologically, symptoms may develop due to abnormalities in either excitatory or inhibitory innervation to either the LES or the esophageal body. As an example, unopposed excitatory innervation to the body of the esophagus is associated with high-amplitude contractions that characterize NE and DES [18]. Although the exact incidence and prevalence of these disorders is not known, several studies have estimated that $11.4-33 \%$ of patients referred for esophageal manometry have one of these disorders $[19,20]$.

The treatment of non-achalasia motility disorders includes medical therapy, endoscopic therapy, and surgery. Previous studies have shown that neither metoclopramide nor domperidone effectively stimulate esophageal body motility, although both agents increase LES resting pressure in healthy volunteers $[21,22]$. Although several studies initially reported that cisapride increased both LES pressure and the amplitude of contractions in the distal esophagus [23-25], a number of other studies failed to confirm any direct prokinetic effects of cisapride on the esophagus $[20,26]$. No studies evaluating the effects of metoclopramide, domperidone, or cisapride on esophageal motor function have been published in the last 5 years.

Erythromycin acts as a motilin agonist and has welldocumented gastrokinetic effects (see below). The effects of intravenous erythromycin $(200 \mathrm{mg}$ ) on esophageal mo- 
tility were assessed in 18 healthy volunteers in a doubleblinded, randomized study [27]. Compared to placebo, erythromycin significantly increased the amplitude of contractions in the distal esophagus, increased the duration of esophageal peristalsis, and increased the resting pressure of the LES. These effects were felt to be due to stimulation of cholinergic pathways, since they could be blocked by pretreatment with atropine. Similar findings were demonstrated in a study of 15 patients with gastroesophageal reflux disease (GERD) [28]. In a study of 45 patients with non-insulin-dependent diabetes mellitus, oral erythromycin (250 mg p.o., q.a.c.) shortened mean transit time in the esophagus and accelerated gastric emptying [29]. In a similar manner, intravenous clarithromycin was shown to increase LES tone, and both the amplitude and duration of esophageal contractions, in a doubleblind, placebo-controlled study of 15 normal volunteers [30]. In a randomized, double-blind, placebo-controlled trial, ABT-229, a motilin agonist, did not affect LES tone, esophageal motility, or the incidence of transient LES relaxations (TLESRs) in 24 GERD patients [31].

Baclofen, a selective $\gamma$-aminobutyric acid agonist, reduced the number of TLESRs in patients with GERD [32]. A double-blind, placebo-controlled, cross-over study of 37 patients with GERD confirmed that baclofen reduces the incidence of reflux episodes by inhibiting TLESRs [31]. Baclofen did not affect LES pressure or esophageal clearance.

Previous studies in healthy volunteers revealed that $6 \mathrm{mg}$ of subcutaneous sumatriptan, a 5- $\mathrm{HT}_{1}$ agonist, increased LES tone and the amplitude of contractions in the distal esophagus [33]. Sumatriptan also affects the frequency of post-prandial TLESRs [34]. A double-blind, randomized, cross-over trial of 10 patients with IEM found that $6 \mathrm{mg}$ of subcutaneous sumatriptan increased the number of swallows and the number of primary esophageal motor waves. In contrast to healthy volunteers, however, sumatriptan did not influence LES tone or the amplitude of contractions [35].

Tegaserod, a specific 5- $\mathrm{HT}_{4}$ receptor partial agonist, initiates gut peristalsis, stimulates chloride secretion in the small intestine, and alters visceral sensation [36]. A prospective, double-blinded trial of 19 patients compared four different doses of tegaserod to placebo over separate 2 -week trial periods [37]. Low-dose tegaserod ( $1 \mathrm{mg} /$ day) reduced post-prandial esophageal acid exposure and decreased the number of post-prandial reflux episodes. No significant changes were identified in LES resting pressure or in the amplitude of distal esophageal contractions.
Mosapride, a benzisoxazole derivative, is a selective 5- $\mathrm{HT}_{4}$ agonist; its main metabolite is a $5-\mathrm{HT}_{3}$ antagonist [38]. A prospective, randomized, blinded, cross-over study of 41 patients with GERD compared mosapride to cisapride [39]. Mosapride (30 mg p.o. t.i.d.) improved several parameters of acid reflux (duration of longest episode of reflux, reflux fraction time), and slightly increased the amplitude of contractions in the lower esophageal body. LES function was not reported in this study. Mosapride increased the rate of esophageal bolus transit, measured by multichannel intraluminal impedance manometry, in a study of 20 healthy volunteers using a double-blinded, placebo-controlled, cross-over design [40]. No changes were noted, however, in LES pressure or amplitude, duration, and velocity of esophageal body contractions.

Two separate studies found that sildenafil $(50 \mathrm{mg}) \mathrm{re}-$ duces elevated LES tone and the amplitude of contractions in the distal esophageal body in patients with isolated hypertensive LES [41, 42]. A recent study of patients with hypercontractile motility disorders demonstrated that sildenafil reduced the amplitude of contractions by more than $70 \%$ in both healthy volunteers and patients, although improvement in symptoms occurred in only $36 \%$ of subjects, and $50 \%$ of these patients had significant side effects [43].

Itopride, a benzamide derivative shown to stimulate gastric motility [44], has primarily been evaluated in dyspepsia and gastroparesis (see below). The utility of itopride was assessed in a study of 26 patients with mild acid reflux disease [45]. Patients with mild esophagitis (Savary-Miller Grade I or II) were randomized to either 50 or $100 \mathrm{mg}$ of itopride t.i.d. for 4 weeks. Compared to placebo, patients treated with either dose of itopride noted a significant improvement in reflux symptoms compared to baseline. Patients treated with $300 \mathrm{mg}$ of itopride daily also had a statistically significant improvement in $\mathrm{pH}$ measurements compared to baseline. Esophageal motility was not assessed in this study, and thus the mechanism of reduced acid exposure remains unclear.

In an interesting use of theophylline, Rao et al. [46] demonstrated in an open-label trial that this adenosine antagonist increased the sensory threshold for distention induced chest pain. No changes in motor function were noted, and a placebo-controlled, blinded study has yet to be performed.

The beneficial effects of BTX in patients with achalasia led to its use in other motility disorders of the esophagus. BTX of the LES relieved symptoms, and normalized manometric abnormalities, in a patient with hyper- 
tensive LES [47]. Nine patients with DES were treated with multiple intraesophageal injections of BTX (100 U total) [48]. Eight of 9 patients had a significant reduction in total symptom score (chest pain, dysphagia, regurgitation) at 4 weeks, and these effects persisted for 6 months. Twenty-nine patients with spastic disorders of the esophagus (DES, hypertensive LES, IEM, NE) were enrolled in an open-label trial to evaluate the efficacy of BTX injection of the LES for the treatment of chest pain [49]. Twenty-one patients $(72 \%)$ responded with at least a $50 \%$ reduction in their chest pain score. The type of underlying motility disorder did not predict response to therapy, although women generally responded better than men.

The role of surgery for patients with esophageal motility disorders remains controversial. In a retrospective review of a prospectively collected database, Patti et al. [19] reported on the results of myotomy in 397 patients with esophageal motility disorders. Of 19 patients with DES, $80-86 \%$ noted an improvement in dysphagia, while $65-80 \%$ noted an improvement in complaints of chest pain. Of 12 patients with NE, $60-83 \%$ reported an improvement in dysphagia, while $40-50 \%$ reported a good or excellent response for their symptoms of chest pain. A smaller study of 16 patients with spastic disorders of the esophagus found that resting pressure and relaxation of the LES improved after long myotomy, although peristalsis did not [50]. In general, patients with a diverticulum and localized manometric abnormalities did better than patients with a diffuse pattern of disordered motility.

Antireflux surgery is now one of the most commonly performed elective surgeries. During pre-operative evaluation most patients undergo esophageal manometry, and many are identified as having a motility disorder of the esophagus. Of 239 patients referred for antireflux surgery, $57(24 \%)$ were identified as having a non-specific motility disorder of the esophagus [51]. In this study, all named esophageal motility disorders (achalasia, DES, NE, hypertensive LES) were excluded from further analysis. The majority of patients underwent laparoscopic Nissen fundoplication; median follow-up was 30 months. Overall, patients with non-specific motility disorders were found to do as well post-operatively as patients with normal pre-operative esophageal manometry. In a similar light, Heider et al. [52] reported that 48 of 262 patients referred for antireflux surgery had IEM. Nineteen of these patients agreed to perform follow-up manometry after surgery, and only 1 had a worsening of esophageal motility. These data, combined with previously published studies, support the concept that complete fundo- plication is unlikely to produce significant dysphagia or chest pain in patients with minor or mild disorders of esophageal motility.

Gastric banding is now frequently performed for morbid obesity. A recent study found that gastric banding reduced the amplitude of contractions in the distal esophagus, although LES tone was not affected [53]. This raises the question of whether morbidly obese patients identified pre-operatively with IEM and acid reflux should be referred for an alternative procedure, such as a Rouxen-Y gastric bypass.

Finally, electrical acupoint stimulation was recently evaluated to determine its effect on TLESRs in a study of 14 healthy volunteers [54]. Electric acupoint stimulation inhibited the frequency of TLESRs compared to sham stimulation, although it did not change LES pressure, esophageal motility, or the duration of TLESRs.

\section{Dyspepsia}

Dyspepsia is defined as discomfort or pain centered in the upper abdomen, often associated with negative symptoms of fullness, bloating or early satiety $[55,56]$. Symptoms tend to wax and wane, and relapse is common. Dyspepsia is categorized into two large groups: organic and functional dyspepsia. Once investigated, the majority of patients are diagnosed with functional dyspepsia [57]. Functional dyspepsia (FD) is defined as at least a 3-month history of dyspeptic symptoms for which no definite structural or biochemical explanation can be found [58]. Patients with classic symptoms of heartburn are excluded from the formal definition of dyspepsia.

The optimal initial evaluation and management of dyspepsia continues to be debated [59-61]. Options include: prompt endoscopy; empiric therapy with an antisecretory or a prokinetic agent, or a 'test-and-treat' strategy for Helicobacter pylori [62]. Up-front endoscopy reduces patient anxiety, with an improvement in patient sense of well-being within the first week of endoscopy [63]. In patients with uninvestigated dyspepsia, endoscopy led to improved patient satisfaction regardless of the findings [64]. The cost-effectiveness of prompt endoscopy, especially in the younger patient, has been questioned [65].

Empiric treatment with an antisecretory agent is commonly employed since many dyspeptic patients have increased acid sensitivity [66]. Concerns with empiric therapy focus on the likelihood of missing an organic lesion. However, recent studies suggest improved patient satis- 
faction and outcome with prompt endoscopy and testand-treat strategy, as discussed below.

The role of H. pylori in FD continues to evolve. Several trials have demonstrated that test-and-treat strategies have outcomes similar to prompt endoscopy, and are more effective than a short course of PPI alone [67-69]. At present, no clear association exists between $H$. pylori and symptoms of FD, and the benefit of $H$. pylori therapy on symptoms continues to be debated [70-73]. A recent meta-analysis of 17 randomized controlled trials found that there was an $8 \%$ relative risk reduction in the eradication group and the number needed to treat to cure 1 case of dyspepsia was 18 [74]. Thus, eradication of $H$. pylori appears to have a small, but statistically significant effect in FD.

Lifestyle modifications are often prescribed for the treatment of dyspepsia, although no studies have been published on this subject in the last 5 years. As such, antisecretory agents such as H2RAs and PPIs are a mainstay of therapy for FD. The efficacy of these treatments remains unclear, however, due to flawed study designs with failure to exclude patients with peptic ulcer disease and predominant GERD. A meta-analysis on the use of H2RAs found that these agents had little or no benefit when compared to placebo [75], although famotidine has demonstrated some promise in the treatment of FD [76-78]. A randomized, placebo-controlled trial comparing omeprazole, ranitidine, cisapride and placebo demonstrated superior symptom relief with omeprazole [79].

Prokinetic therapy is often employed in the treatment of FD, since nearly $40 \%$ of patients demonstrate a mild to moderate delay in gastric emptying [80]. Although metoclopramide is commonly used, its efficacy has been questioned in a recent meta-analysis [81]. On the other hand, another meta-analysis of 8 studies found domperidone to be more effective than placebo at improving global symptoms, with an odds ratio of 7.0 [82].

Tegaserod, a partial selective 5-HT 4 agonist, has been shown to accelerate gastric emptying [83]. Preliminary studies demonstrate improved upper GI symptoms in female patients with FD [84]. Mosapride, another 5-HT receptor agonist, has also improved some symptoms of FD in an early clinical trial [85].

Itopride hydrochloride is a benzamide derivative and acts as a dopamine antagonist. In an open-label, noncomparative study, itopride (50 mg t.i.d) was well tolerated and relieved symptoms of dyspepsia [86]. Another study found itopride to be comparable to domperidone in providing symptom relief [87].
Levosulpiride, another dopamine antagonist, decreases the perception of gastric distention [88]. In FD patients, levosulpiride was found to be as effective as cisapride [89] at providing symptom relief.

The chronic abdominal pain of FD can be difficult to treat. Tricyclic antidepressants have been used with modest success $[90,91]$. Fluoxetine did not lead to any improvement in FD patients, as evaluated by electrogastrography [92]. Alosetron, a 5- $\mathrm{HT}_{3}$ receptor antagonist has also shown potential benefit in decreasing upper abdominal pain [93].

Fundic relaxation may be impaired in patients with FD, leading to symptoms of post-prandial pain, discomfort, and nausea. 5- $\mathrm{HT}_{1}$ agonists such as sumatriptan and buspirone should theoretically increase gastric accommodation and improve symptoms in a subset of FD patients. Large controlled trials have not yet been performed, however. Clonidine, an $\alpha$-adrenergic receptor agonist, may also decrease pain perception with gastric distention [94].

A number of non-conventional therapies have been used in the treatment of dyspepsia, including ginger, peppermint oil, caraway oil, red pepper (capsaicin) and Iberogast (combination of 9 different herbs). One small randomized study showed some benefit of capsaicin compared to placebo [95]. A meta-analysis found Iberogast to be more effective at relieving symptoms than placebo [96]. Artichoke leaf extract may also improve some symptoms of dyspepsia [97, 98].

Psychotherapy, behavioral therapy and hypnotherapy all may have a role in the treatment of dyspepsia, although their efficacy has not been clearly established [99-103]. It appears that symptom pattern and psychological characteristics are independent predictors of treatment response, with patients having high scores for reflux-like symptoms and high scores for somatization demonstrating greater response to acid suppressants [104].

\section{Gastroparesis}

Gastroparesis is defined as the impaired transit of intraluminal contents from the stomach to the duodenum in the absence of mechanical obstruction. Diabetes accounts for $25 \%$ of cases, while idiopathic gastroparesis accounts for nearly 50\% [105].

The goals of treatment include relief of symptoms, improved nutrition, and the prevention of complications, such as bezoar formation. Therapeutic intervention is often multidimensional, including diet, lifestyle changes, 
and medications. If a patient is unable to maintain adequate nutritional status, total parenteral nutrition or a jejunostomy feeding tube may be required [106].

Small, frequent meals are an essential component of therapy. Meals should be low in fiber, to prevent bezoar formation, and low in fat, as fat delays gastric emptying. Liquids should be emphasized over solid foods. A recent study found that walking after eating increases the normal 3 -cpm activity in the stomach and thus may improve gastric emptying in some patients [107].

A large number of antiemetic agents are now available to treat nausea in gastroparetic patients [108]. The most commonly used agents include phenothiazines and 5$\mathrm{HT}_{3}$ receptor antagonists. Antihistamines exhibit central antiemetic effects and, though well established for use of motion sickness, the efficacy in gastroparesis is not well described [109]. Other agents that have been used include benzodiazepines and cannabinoids. Given the refractory nature of nausea, patients frequently require multiple agents, usually one each from different chemical classes.

Prokinetic agents used in the treatment of gastroparesis include metoclopramide, erythromycin, domperidone and tegaserod. Metoclopramide has both prokinetic and antiemetic properties [110]. No studies evaluating the utility of metoclopramide in gastroparetic patients have been published in the last 5 years. Erythromycin is a potent gastrokinetic [111-115], although its efficacy in relieving symptoms has not been clearly demonstrated [116]. GM-611, a motilin agonist, is under development. Preliminary animal studies have shown that this agent accelerates gastric emptying; its effects in the human GI tract have not been characterized.

Domperidone, another dopamine antagonist, improves symptoms and quality of life in patients with diabetic gastroparesis, although this medication is not readily obtainable in the USA [117-119].

Tegaserod, a selective 5- $\mathrm{HT}_{4}$, increases gastric emptying in diabetic mice, increases gastric emptying in patients with dyspepsia and delayed gastric emptying, and increases orocecal transit time in women with constipation $[36,120,121]$. Tegaserod has also been shown to accelerate gastric emptying, small intestinal transit and colonic transit in healthy male subjects [122]. In a small case series, tegaserod was successfully used as a prokinetic agent in critically ill patients with impaired gastric motility [123]. Tegaserod is not yet approved by the FDA for use in gastroparetic patients.

Cisapride, a mixed 5- $\mathrm{HT}_{4}$ agonist/5- $\mathrm{HT}_{3}$ antagonist, is available only under limited use. No studies have been published in the last 5 years on the efficacy of cisapride in gastroparesis.

Preliminary studies have shown that mosapride has prokinetic effects on many areas of the GI tract [124, 125]. In one study, mosapride improved gastric motility in diabetic gastropathy and also improved glycemic control with a corresponding decrease in $\mathrm{HgA1C}$ [126, 127].

Other new prokinetic agents under investigation include the dopamine receptor antagonist levosulpiride and the cholecystokinin receptor antagonist loxiglumide [128, 129]. In animal studies, itopride increases gastric motility through its antidopaminergic and antiacetylcholinesterase actions [130].

In patients with refractory gastroparesis, psychotropic medications such as tricyclic antidepressants may provide relief of nausea, vomiting and associated abdominal pain [131, 132]. Alternative therapies include ginger [133], acupuncture with stimulation of the PC6 point on the wrist [134, 135], or the ST36 (Zusanli) point below the patella [136].

Endoscopic and surgical interventions are now available for gastroparetic patients with refractory symptoms. Endoscopically, BTX injection into the pylorus inhibits the release of acetylcholine from synaptic vesicles at the synaptic junction, thereby inducing a state of transient muscle paralysis. Efficacy of BTX has been demonstrated in diabetic gastroparesis as well as idiopathic gastroparesis. Long-term outcomes have not been determined to date $[137,138]$.

Surgical options include gastric resection and gastric electrical stimulation. In general, gastric resection appears to be of limited benefit and should only be used as a last resort for patients with profound symptoms and gastric stasis [139, 140]. Gastric electrical stimulation (GES) uses an implantable neurostimulator that delivers a high-frequency, low-energy signal with short pulses. An initial study showed a decrease in nausea and vomiting in 20 of 26 patients at 3 and 6 months after implantation [141]. A second study of the implantable neurostimulator involved a double-blind sham stimulation-controlled trial for 2 months followed by activation of all devices for 1 year [142]. The study consisted of 33 patients with either diabetic or idiopathic gastroparesis. Of 33 patients, 21 preferred having the stimulator in the 'on' mode. In phase 2 of the trial, all devices were turned on. Follow-up at the end of 1 year showed a relative decrease in vomiting frequency from 25 to 6 times per week with associated improvements in quality of life, primarily in the diabetic gastroparesis subgroup. A subset of 12 patients in 
the Gastric Electromechanical Stimulation (GEMS) Study Group was extensively evaluated with regards to nutritional parameters before and after stimulator implantation. GES improved symptoms in addition to body weight, body mass index and serum albumin at 3 and 6 months [143]. A small study of diabetic patients with drug-refractory gastroparesis showed symptom improvement after GES implantation and also improved glycemic control at 6 and 12 months [144]. Despite significant cost of the device and its implantation, in the long term, GES may be more cost effective than intensive medical therapy [145].

\section{Chronic Intestinal Pseudo-Obstruction}

Chronic intestinal pseudo-obstruction (CIP) is characterized by signs and symptoms (present for at least 6 months) which suggest mechanical obstruction of the intestinal tract. While the clinical symptoms of CIP are usually indistinguishable from mechanical obstruction, the etiology, pathology and treatment are quite different. First identified in 1958, it is estimated that approximately 100 infants are born each year in the USA with congenital pseudo-obstruction. CIP may be categorized as primary (neuropathic, myopathic, or mesenchymopathic), secondary (collagen vascular disease, endocrine, neoplastic, neurologic), or idiopathic in nature [146, 147]. The most common symptoms of CIP are abdominal pain, vomiting, bloating, constipation, and diarrhea. Additional symptoms may include dysphagia, reflux, early satiety, and genitourinary symptoms, such as difficulty voiding. Treatment options for CIP are limited, and focus on correcting nutritional deficiencies, minimizing symptoms, and preventing weight loss and malnutrition. Previous treatments have included cisapride, domperidone, metoclopramide, and octreotide - although none have been uniformly successful [146].

A recent study evaluated the effects of oral erythromycin (500 mg t.i.d. or q.i.d.) in 15 consecutive patients with CIP who had failed standard medical therapy [148]. Six patients (40\%) responded with a decrease in nausea, vomiting, and abdominal pain. Men appeared to respond better than women, and responders were less likely than nonresponders to be taking long-term narcotics.

Neostigmine, an acetylcholinesterase inhibitor, is used to treat acute colonic pseudo-obstruction [149]. A recent case report describes the daily use of neostigmine ( $2 \mathrm{mg}$ i.v. q $6 \mathrm{~h}$ ) for several months in a hospitalized patient with chronic colonic pseudo-obstruction [150]. To date, neostigmine has not been studied in a controlled manner in patients with CIP. No formal trials have been conducted to date using tegaserod, mosapride, renzapride, or levosulpiride; although all of these prokinetic agents theoretically could improve symptoms in patients with CIP.

Surgery is generally avoided in patients with CIP, for fear of precipitating an acute episode. However, intestinal transplantation may be a viable treatment for patients with severe CIP who cannot be maintained on parenteral nutrition. Six patients with CIP underwent intestinal transplantation (isolated small bowel in 5, and stomach, duodenum, pancreas, and small bowel in 1) after medical management had failed [151]. Mean follow-up was 25 months. All 5 patients who underwent isolated small bowel transplant survived, and 3 were able to stop parenteral nutrition; the 1 patient who underwent a more extensive graft died from hemolytic-uremic syndrome. Multivisceral transplantation has been described in pediatric patients (median age 4 years) with severe CIP [152]. Ten patients survived after 2 years; all were off parenteral nutrition and were tolerating enteral feedings.

\section{Irritable Bowel Syndrome}

Irritable bowel syndrome (IBS) is characterized by abdominal pain with disturbed defecation [153]. IBS is highly prevalent and is associated with a significant reduction in quality of life [154]. A large number of clinical studies have been published over the last 5 years in the field of IBS. For patients with IBS and constipation, fiber supplementation may improve symptoms of constipation, although abdominal pain is unlikely to improve [155-157]. Tegaserod, a 5- $\mathrm{HT}_{4}$ agonist, improves global symptoms of IBS and constipation in women with constipation-predominant IBS [158, 159]. Renzapride, a mixed $5-\mathrm{HT}_{4}$ receptor agonist $/ 5-\mathrm{HT}_{3}$ receptor antagonist, accelerates colonic transit in constipation-predominant IBS patients [160]. Based on animal studies, mosapride, another $5-\mathrm{HT}_{4}$ receptor agonist, may have a role in the treatment of constipation-predominant IBS [124, 125].

For diarrhea-predominant IBS, loperamide can reduce loose stools, urgency and fecal soiling [161, 162]. Alosetron, a 5- $\mathrm{HT}_{3}$ receptor antagonist, was shown to improve diarrhea and urgency in women [163, 164]. Alosetron was removed from the market by the FDA due to concerns over an association with ischemic colitis. Re- 
cently, patients with IBS have been shown to have a twoto-fourfold increased risk of ischemic colitis, so the actual medication risk of alosetron is unclear [164, 165]. Preliminary data on cilansetron, another $5-\mathrm{HT}_{3}$ receptor antagonist, shows that this medication may improve symptoms of IBS and diarrhea in both men and women. A review by the FDA in the spring of 2005 did not lead to a letter of approval, however, and further clinical trials were requested.

Smooth muscle antispasmodics alleviate symptoms of abdominal pain and bloating in some patients with IBS. In one meta-analysis, 5 drugs showed efficacy over placebo (cimetropium bromide, pinaverium bromide, octylonium bromide, trimebutine, and mebeverine) [166]. Although commonly used in the clinical setting, this meta-analysis did not show that dicyclomine and hyoscyamine were effective. Tricyclic antidepressants (TCAs) and serotonin reuptake inhibitors (SSRIs) have been shown to alter visceral sensitivity, reduce central pain perception, and treat concurrent psychiatric co-morbidities. It is thought that TCAs work centrally rather than peripherally to reduce pain [167]. A recent Cochrane database review found that, in IBS patients, the relative response to TCAs was 1.34 and the number needed to treat was 6. Low-dose TCAs may be helpful if pain is constant in nature, rather than intermittent. SSRIs may improve visceral hypersensitivity, particularly in constipationpredominant IBS, although the efficacy of this class of medications continues to be debated [168, 169]. Finally, SSRIs have been shown to improve patients' sense of well-being, even in non-depressed patients [170].

In addition to medical therapy, a number of different psychological interventions have been evaluated. In a randomized trial in the primary care setting, cognitive behavior therapy, in addition to antispasmodic treatment, showed additional benefits when compared to medication therapy alone at 6 months, although the effects had waned by 12 months [171]. Overall, the efficacy of psychological intervention remains unclear [172, 173].

Probiotics are a potential new therapy for the treatment of IBS [174]. It is believed that probiotics act to normalize the ratio of anti-inflammatory to pro-inflammatory cytokines in the gut, thereby alleviating symptoms. A recent trial showed improvement in cytokine balance with associated improved QOL assessments in patients taking Bifidobacterium (B. infantis 35624) in a malted milk drink [175].

Newer agents under current investigation, all of which require further study, include CCK1 receptor antagonists and tachykinins. Asimadoline, a k-opioid agonist, showed decreased overall perception of pain with colonic distention in a study of female patients with IBS [176].

Alternative therapies are commonly used by patients with IBS. Dried turmeric extracts improved IBS symptoms when compared to placebo in a partially blinded randomized pilot study [177]. Two small pilot studies in diarrhea-predominant IBS patients suggest that transcutaneous electrical acustimulation at ST36 and P6, but not sham stimulation, increased the threshold of rectal sensation of gas, desire to defecate and pain [178, 179]. Finally, hypnosis has been reported to improve global IBS symptoms in a recent study and review $[180,181]$.

\section{Chronic Constipation}

Chronic constipation is not a single disorder, but instead represents a number of different pathophysiologic processes, including colonic inertia, normal transit constipation, and pelvic floor dyssynergia [182, 183]. Many patients suffer from two of these processes at the same time (i.e., both colonic inertia and pelvic floor dysfunction). The data presented below is thus for a heterogeneous group of patients, rather than for a pure population of patients with only one pathophysiologic abnormality.

The prevalence of chronic constipation is estimated at $12-19 \%$, while the incidence is estimated at 4 per 100 person-years of follow-up [184, 185]. Although studies are limited, chronic constipation can both reduce patients' quality of life and impose a substantial economic burden [186].

Lactulose, a non-absorbable synthetic disaccharide, has been used to treat constipation for over 20 years. Only one study using lactulose in patients with chronic constipation has been published since 2000. This study employed a parallel-group, multicenter, randomized design and compared lactulose (33 patients) to polyethylene glycol (PEG) (32 patients). No significant difference was found between the groups with regard to stool frequency, stool consistency, or straining [187]. A recent systematic review found that lactulose was less effective than PEG or bulk laxatives at relieving symptoms of constipation [188].

PEG is a large, non-absorbable, chemically inert polymer which acts as an osmotic agent to retain water in the stool. Cleveland et al. [189] conducted a randomized, double-blind, cross-over study in 23 patients and compared PEG (17 g/day) to placebo over a 2-week trial period. PEG was found to improve stool frequency and 
stool consistency; no discontinuations were reported. DiPalma et al. [190] randomized 151 patients to either PEG $(17 \mathrm{~g} /$ day) or placebo in a double-blinded, multicenter study which lasted 10 days. No significant adverse events were reported in the 135 patients who completed the study. PEG was found to be statistically superior to placebo in regards to stool frequency and stool passage. Similar results on the efficacy of PEG have been reported elsewhere [191].

Two large randomized, placebo-controlled trials have been performed to evaluate the efficacy and safety of tegaserod in the treatment of chronic constipation. Kamm et al. [192] compared tegaserod (2 or $6 \mathrm{mg}$ ) to placebo in 1,264 women and men over a 12 -week trial period. The primary efficacy variable was the responder rate for complete spontaneous bowel movements during the first 4 weeks of treatment. Both the 6- and 2-mg dose, given b.i.d., were more effective than placebo ( $p<0.0001$ and $\mathrm{p}<0.01$, respectively). In another randomized, doubleblind, placebo-controlled of 1,348 men and women with chronic constipation, Johanson et al. [193] found that both $2 \mathrm{mg}$ and $6 \mathrm{mg}$ b.i.d. were more effective than placebo at increasing the number of complete spontaneous bowel movements.

Prucalopride, a 5- $\mathrm{HT}_{4}$ agonist, has been shown to accelerate GI transit and improve symptoms of constipation in several different studies. In a double-blind, parallel-group design of 40 patients with functional constipation but without evidence of a rectal evacuation disorder, $4 \mathrm{mg}$ of prucalopride accelerated gastric, small bowel, and colonic transit [194]. Emmanuel et al. [195], in a doubleblind, placebo-controlled trial of 74 patients, found that $1 \mathrm{mg}$ of prucalopride daily accelerated orocecal transit, increased stool frequency, and improved symptoms of constipation. A 4-week, double-blind, placebo-controlled trial found that $4 \mathrm{mg}$ of prucalopride daily improved whole gut transit, reduced straining, and reduced time to first stool in 53 patients with chronic constipation [196]. Finally, prucalopride (either 1 or $2 \mathrm{mg}$ ) was shown to improve symptoms of constipation and reduced mean colonic transit time in a double-blind, placebo-controlled, cross-over study of 28 patients with chronic constipation [197]. Concerns over possible cardiac arrhythmias with prucalopride use have halted further studies for now.

Neurotrophin-3 (NT-3) is a neurotrophic growth factor that enhances the growth and development of neurons, especially those of the enteric nervous system. A double-blind, randomized, placebo-controlled, multicenter study was performed using NT-3 in 107 patients with functional constipation (Rome II criteria). Patients were randomized to placebo, $3 \mathrm{mg}$, or $9 \mathrm{mg}$ of NT-3 given subcutaneously either weekly or three times weekly [198]. Colon transit time and stool frequency were the primary endpoints measured. Weekly dosing of NT-3 was not effective, although $9 \mathrm{mg}$ of NT-3 given three times weekly led to a significant improvement in stool frequency, stool consistency, and straining. In addition, colonic transit was accelerated. The clinical utility of this agent will likely be limited by the fact that patients will require an injection, and also by the fact that $33-50 \%$ of the patients who received NT-3 had injection site reactions.

Lubiprostone is a bicyclic fatty acid that acts to open specific chloride channels (ClC-2) within the GI tract, thereby enhancing fluid secretion. It is not presently known whether this agent acts with greater affinity or specificity in one portion of the GI tract compared to another. Although clinical data is limited and still mostly in abstract form, it appears that this oral medication does not appear to alter electrolyte levels in either normal volunteers or patients. A multicenter, randomized, doubleblinded study showed that $24 \mu \mathrm{g}$ b.i.d. of lubiprostone was more effective than placebo with regards to improving stool frequency, stool consistency, and straining [199]. Several studies involving lubiprostone and patients with chronic constipation were recently presented at the annual meeting of the American College of Gastroenterology in October 2005. Lubiprostone ( $24 \mu \mathrm{g}$ b.i.d.) was compared to placebo in a multicenter, parallel-group, 4week, double-blind study of 237 patients with idiopathic constipation [200]. More patients treated with lubiprostone noted a spontaneous bowel movement within the first $24 \mathrm{~h}$, compared to placebo $(\mathrm{p}<0.001)$. Stool frequency over the 4-week trial period was significantly improved for the lubiprostone group compared to placebo $(\mathrm{p}<0.05)$. One concern from these studies, however, is that lubiprostone has been associated with a significant incidence of nausea - up to $31.7 \%$ of all subjects in one study. Publication of the data in full manuscript form is eagerly awaited.

Mosapride, a 5- $\mathrm{HT}_{4}$ agonist with $5-\mathrm{HT}_{3}$ antagonist properties, has been evaluated in an open-label study of 14 Parkinsonian patients with constipation [201]. Both subjective (straining, difficulty with evacuation), and objective (frequency) measurements of constipation and colon motility (colonic transit time and rectoanal videomanometry) were recorded at baseline and after 3 months of treatment with $15 \mathrm{mg} /$ day. Mosapride improved symptoms of constipation (frequency and straining) and also improved colonic transit time, particularly in the left co- 
lon. Mosapride also resulted in larger amplitude of rectal contractions.

Alvimopan is a novel orally active $\mu$-opioid receptor antagonist [202]. Early studies have focused on the role of alvimopan on reversing narcotic-induced constipation and improving post-operative ileus. A recent abstract reported that alvimopan improves whole bowel transit time in adults with chronic constipation [203].

Biofeedback has been evaluated in a number of studies of patients with chronic constipation due to pelvic floor dysfunction. However, no placebo or sham controlled trials have been performed in adults. A recent study of 52 patients confirms the clinical view that biofeedback is effective at treating symptoms of constipation due to pelvic floor dyssynergia, although it is not effective at treating constipation due to slow transit constipation [204]. For further details, the reader is referred to a recent comprehensive review that nicely summarizes studies performed to date for biofeedback and functional anorectal disorders [205].

\section{Conclusions}

Motility disorders of the GI tract are highly prevalent in the clinical setting and are now readily diagnosed in the motility laboratory. In the last 5 years, several advances have taken place, notably the development of multichannel impedance, increasing use of electrogastrography, and greater clinical use of gastric stimulation. A number of new therapies are now available to treat symptoms of GI dysmotility. Many of these target the serotonin system, which has been recognized as playing a critical role in normal gut pathophysiology. However, due to ever increasing concerns over safety, future studies of medications will need to be performed for longer periods of time, involve more patients, include an extended investigation time. Finally, although at least $35 \%$ of adults routinely use some form of alternative or complementary medication, there are few well-designed trials evaluating the efficacy and safety of these agents. These will be required if these agents are to become accepted by the clinician.

\section{References}

1 El-Serag HB, Talley NJ: Health-related quality of life in functional dyspepsia. Aliment Pharmacol Ther 2003;18:387-393.

-2 Yunus TM, Mathis C, Grabbe KM, Heinberg LJ, Lacy BE: Quality of life in patients with gastroparesis. Am J Gastroenterol 2003;98: S57.

- 3 Pare P, Ferrazzi S, Thompson WG, Irvine EJ, Rance L: An epidemiological survey of constipation in Canada: definitions, rates, demographics, and predictors of health care seeking. Am J Gastroenterol 2001;96:3130-3137.

4 Gralnek IM, Hays RD, Kilbourne A, Naliboff B, Mayer EA: The impact of irritable bowel syndrome on health-relate quality of life. Gastroenterology 2000;119:654-660.

-5 Lacy BE, Barghout V, Bauer D: Gastroparesis. The impact on work and daily activities. Am J Gastroenterol 2005;100:S332.

-6 Sandler RS, Everhart JE, Donowitz M, Adams E, Cronin K, Goodman C, Gemmen E, Shah S, Avdic A, Rubin R: The burden of selected digestives diseases in the United States. Gastroenterology 2002;122:1500-1511.

7 Talley NJ, Gabriel SE, Harmsen WS, Zinmeister AR, Evans RW: Medical costs in community subjects with irritable bowel syndrome. Gastroenterology 1995;109:1736-1741.

8 Podas T, Eaden J, Mayberry M, Mayberry J: Achalasia: a critical review of epidemiological studies. Am J Gastroenterol 1998;93:23452347.
9 Wong RKY, Maydonovitch CL: Achalasia; in Castell DO, Richter JE (eds): The esophagus, ed 3. Philadelphia, Lippincott Williams \& Wilkins, 1999, pp 185-213.

10 Vaezi MF, Baker ME, Achkar E, Richter JE: Timed barium oesophagram: better predictor of success after pneumatic dilation in achalasia than symptom assessment. Gut 2002;50:765770.

11 West RL, Hirsch DP, Bartelsman JF, de Borst JFWM, Ferwerda G, Tytgat GN, Boeckxstaens GE: Long-term results of pneumatic dilation in achalasia followed for more than 5 years. Am J Gastroenterol 2002;97:1346-1351.

12 Katz PO, Gilbert J, Castell DO: Pneumatic dilation is effective long-term treatment for achalasia. Dig Dis Sci 1998;43:1973-1977.

13 Vela MF, Richter JE, Wachsberger D, Connor J, Rice TW: Complexities of managing achalasia at a tertiary referral center: use of pneumatic dilatation, Heller myotomy, and botulinum toxin injection. Am J Gastroenterol 2004; 99:1029-1036.

14 Bortolotti M, Mari C, Giovannini M, Pinna S, Miglioli M: Effects of sildenafil on esophageal motility of normal subjects. Dig Dis Sci 2001; 46:2301-2306.

15 Lee JI, Park H, Kim JH, Lee SI, Conklin JL: The effect of sildenafil on oesophageal motor function in healthy subjects and patients with nutcracker esophagus. Neurogastroenterol Motil 2003;15:617-623.
16 Bortolotti M, Mari C, Lopilato C, Porrazzo G, Miglioli M: Effects of sildenafil on oesophageal motility of patients with idiopathic achalasia. Gastroenterology 2000;118:253-257.

17 Richter JE: Oesophageal motility disorders. Lancet 2001;358:823-828.

18 Murray JA, Ledlow A, Launspach J, Evans D, Loveday M, Conklin JL: The effects of recombinant human hemoglobin on oesophageal motor function in human. Gastroenterology 1995; 109:1241-1248.

19 Patti MG, Gorodner MV, Galvani C, Tedesco P, Fisichella PM, Ostroff JW, Bagatelos KC, Way LW: Spectrum of esophageal motility disorders. Implications for diagnosis and treatment. Arch Surg 2005;140:442-449.

20 Katz PO, Dalton CB, Richter JE, Wu WC, Castell DO: Esophageal testing of patients with noncardiac chest pain and/or dysphagia. Results of three years' experience with 1,161 patients. Ann Intern Med 1987;106:593-597.

21 Grande L, Lacima G, Ros E, Garcia-Valdecasas JC, Fuster J, Visa J, Pera C: Lack of effect of metoclopramide and domperidone on esophageal peristalsis and esophageal acid clearance in reflux esophagitis. A randomized, double-blind study. Dig Dis Sci 1992;37:583588 .

22 Ramirez B, Richter JE: Promotility drugs in the treatment of gastro-oesophageal reflux disease. Aliment Pharmacol Ther 1993;7:5-20. 
-23 Gilbert RJ, Dodds WJ, Kahrilas PJ, Hogan WJ, Lipman S: Effect of cisapride, a new prokinetic agent in esophageal motor dysfunction. Dig Dis Sci 1987;32:1331-1336.

-24 Ceccatelli P, Janssens J, Vantrappen G, Cucchiara S: Cisapride restores the decreased lower oesophageal sphincter pressure in reflux patients. Gut 1988;29:631-635.

25 Holloway RH, Downton J, Mitchell B, Dent J: Effect of cisapride in postprandial gastro-oesophageal reflux. Gut 1989;30:1187-1193.

-26 Van Herwaarden MA, Samsom M, Van Nispen CHM, Verlinden M, Smout AJPM: The effect of motilin agonist ABT-229 on gastrooesophageal reflux, oesophageal motility and lower oesophageal sphincter characteristics in GERD patients. Aliment Pharmacol Ther 2000; 14:453-462.

$\checkmark 27$ Koutsoumbi P, Epanomeritakis E, Tsiaoussis $\mathrm{J}$, Athanasakis H, Chrysos E, Zoras O, Vassilakis JS, Xynos E: The effect of erythromycin on human esophageal motility is mediated by serotonin receptors. Am J Gastroenterol 2000; 95:3388-3392.

-28 Chrysos E, Tzovaras G, Epanomeritakis E, Tsiaoussis J, Vrachasotakis N, Vassilakis JS, Xynos E: Erythromycin enhances oesophageal motility in patients with gastro-oesophageal reflux. ANZ J Surg 2001;71:98-102.

-29 Chang CT, Shiau YC, Lin CC, Li TC, Lee CC, $\mathrm{Kao} \mathrm{CH}$ : Improvement of esophageal and gastric motility after 2-week treatment of oral erythromycin in patients with non-insulin-dependent diabetes mellitus. J Diabetes Complications 2003; 17:141-144.

-30 Bortolotti M, Pandolfo N, La Rovere G, Giovannini M, Miglioli M: Effect of clarithromycin on esophageal motility. Dis Esophagus 2000; 13:231-233.

-31 Van Herwaarden MA, Samsom M, Rydholm H, Smout AJPM: The effect of baclofen on gastro-oesophageal reflux, lower oesophageal sphincter function and reflux symptoms in patients with reflux disease. Aliment Pharmacol Ther 2002;16:1655-1662.

-32 Zhang Q, Lehman A, Rigda R, et al: Control of transient lower oesophageal sphincter relaxations and reflux by the GABA-B agonist baclofen in patients with gastro-oesophageal reflux disease. Gut 2002;50:19-24.

- 33 Foster JM, Houghton LA, Whorwell PJ, Morris $\mathrm{J}$ : Altered oesophageal motility following the administration of the 5- $\mathrm{HT}_{1}$ agonist, sumatriptan. Aliment Pharmacol Ther 1999;13: 927-936.

>34 Sifrim D, Holloway RH, Tack J, Zelter A, Missotten T, Coulie B, Janssens J: Effect of sumatriptan, a $5-\mathrm{HT}_{1}$ agonist, on the frequency of transient lower esophageal sphincter relaxations and gastroesophageal reflux in healthy subjects. Am J Gastroenterol 1999;94:31583164.

\35 Grossi L, Ciccaglione AF, Marzio L: Effect of the $5-\mathrm{HT}_{1}$ agonist sumatriptan on oesophageal motor patterns in patients with ineffective oesophageal motility. Neurogastroenterol Motil 2003; 15:9-14.
36 Lacy BE, Yu S: Tegaserod: a new 5- $\mathrm{HT}_{4}$ agonist. J Clin Gastroenterol 2002;34:27-33.

37 Kahrilas PJ, Quigley EMM, Castell DO, Spechler SJ: The effects of tegaserod (HTF 919) on oesophageal acid exposure in gastrooesophageal reflux disease. Aliment Pharmacol Ther 2000;14:1503-1509.

38 Yoshida N, Omoya H, Oka M, Furukawa K, Ito T, Karasawa T: AS-4370, a novel gastrokinetic agent free of dopamine $\mathrm{D}_{2}$ receptor antagonistic properties. Arch Int Pharmacodyn Thér 1989;300:51-67.

39 Ruth M, Finizia C, Cange L, Lundell L: The effect of mosapride on oesophageal motor function and acid reflux in patients with gastrooesophageal reflux disease. Eur J Gastroenterol Hepatol 2003;15:1115-1121.

40 Park JM, Choi MG, Cho YK, et al: The effect of mosapride on esophageal motility in healthy volunteers. Gastroenterology 2005;128:A530.

41 Bortolotti M, Pandolfo N, Giovannini M, Mari C, Miglioli M: Effect of sildenafil on hypertensive lower oesophageal sphincter. Eur J Clin Invest 2002;32:682-685.

42 Mathis C, Lacy BE, Yu S, Desbiens J: Effects of sildenafil on lower esophageal sphincter in patients with hypertensive LES. Am J Gastroenterol 2002;97:S34.

43 Eherer AJ, Schwetz I, Hammer HF, Petnehazy T, Scheidl SJ, Weber K, Krejs GJ: Effect of sildenafil on oesophageal motor function in healthy subjects and patients with oesophageal motor disorders. Gut 2002;50:758-764.

44 Iwanaga Y, Miyashita N, Saito T, Morikawa $\mathrm{K}$, Itoh Z: Gastroprokinetic effect of a new benzamide derivative itopride and its mechanism of action in conscious dogs. Jpn J Pharmacol 1996;71:129-137.

45 Kim YS, Kim TH, Choi CS, Shon YW, Kim SW, Seo GS, Nah YH, Choi MG, Choi SC: Effect of itopride, a new prokinetic, in patients with mild GERD: a pilot study. World J Gastroenterol 2005; 11:4210-4214.

46 Rao SS, Mudipalli RS, Mujica V, Utech CL, Zhao X, Conklin JL: An open-label trial of theophylline for functional chest pain. Dig Dis Sci 2002;47:2763-2768.

47 Lacy BE, Zayat EN, Crowell MD: Botulinum toxin in hypertensive lower esophageal sphincter: a manometric case study. Dysphagia 2002; 17:75-80.

48 Storr M, Allescher HD, Rosch T, Born P, Weigert N, Classen M: Treatment of symptomatic diffuse esophageal spasm by endoscopic injections of botulinum toxin: a prospective study with long-term follow-up. Gastrointest Endosc 2001;54:754-759.

49 Miller LS, Pullela SV, Parkman HP, Schiano TD, Cassidy MJ, Cohen S, Fisher RS: Treatment of chest pain in patients with noncardiac, nonreflux, nonachalasia spastic esophageal motor disorders using botulinum toxin injection into the gastroesophageal junction. Am J Gastroenterol 2002;97:1640-1646.

-50 Nastos D, Chen LQ, Ferraro P, Taillefer R, Duranceau AC: Long myotomy with antireflux repair for esophageal spastic disorders. J Gastrointest Surg 2002;6:713-722.
51 Velanovich V, Mahatme A: Effects of manometrically discovered nonspecific motility disorders of the esophagus on the outcomes of antireflux surgery. J Gastrointest Surg 2004;8: 335-341.

-52 Heider TR, Behrns KE, Koruda MJ, Shaheen NJ, Lucktong TA, Bradshaw B, Farrell TM: Fundoplication improves disordered esophageal motility. J Gastrointest Surg 2003; 7:159163.

53 Suter M, Dorta G, Giusti V, Calmes JM: Gastric banding interferes with esophageal motility and gastroesophageal reflux. Arch Surg 2005; 140:639-643.

54 Zou D, Chen WH, Iwakiri K, Rigda R, Tippett M, Holloway RH: Inhibition of transient lower esophageal sphincter relaxations by electrical acupoint stimulation. Am J Physiol 2005;289: G197-G201.

55 Talley NJ, Silverstein MD, Agreus L, Nyren O, Sonnenberg A, Holtmann G: AGA technical review: evaluation of dyspepsia. Gastroenterology 1998;114:582-595.

56 Talley NJ: Dyspepsia. Gastroenterology 2003; 125:1219-1226.

57 Thomson AB, Barkun AN, Armstrong D, Chiba N, White RJ, Daniels S, Escobedo S, Chakraborty B, Sinclair P, Van Zanten SJ: The prevalence of clinically significant endoscopic findings in primary care patients with uninvestigated dyspepsia: the Canadian Adult Dyspepsia Empiric Treatment-Prompt Endoscopy (CADET-PE). Aliment Pharmacol Ther 2003; 17:1481-1491.

58 Talley NJ, Colin-Jones D, Koch KJ, Koch M, Nyren O, Stanghellini V: Functional dyspepsia: a classification with guidelines for diagnosis and management. Gastroenterol Int 1991; 4:145-160.

59 Nyren O: Therapeutic trial in dyspepsia: its role in the primary care setting. Scand J Gastroenterol 1991;26:61-69.

60 Health and Public Policy Committee: Endoscopy in the evaluation of dyspepsia. Ann Intern Med 1985;102:266-269.

61 Whitaker MJ, Brun J, Carelli F: Controversy and consensus in the management of upper gastrointestinal disease in primary care. The International Gastro Primary Care Group. Int J Clin Pract 1997;51:239-243.

62 Chiba N, Van Zanten SJ, Sinclair P, Ferguson RA, Escobedo S, Grace E: Treating Helicobacter pylori infection in primary care patients with uninvestigated dyspepsia: The Canadian Adult Dyspepsia Empiric Treatment-Helicobacter pylori-Positive (CADET-Hp) randomized controlled trial. BMJ 2002;324:10121018.

63 Wirklund I, Glise H, Jerndal P, Carlsson J, Talley NJ: Does endoscopy have a positive impact on quality of life in dyspepsia? Gastrointest Endosc 1998;47:449-454.

64 Rabeneck L, Wristers K, Souchek J, Ambriz E: Impact or upper endoscopy on satisfaction in patients with previously uninvestigated dyspepsia. Gastrointest Endosc 2003;57:295299. 
65 Silverstein MD, Petterson T, Talley NJ: Initial endoscopy or empirical therapy with or without testing for Helicobacter pylori for dyspepsia: a decision analysis. Gastroenterology 1996; 110:72-83.

- 66 Samson M, Verhagen MA, van Berge Henegouwen GP, Smout AJ: Abnormal clearance of exogenous acid and increased acid sensitivity of the proximal duodenum in dyspeptic patients. Gasteroenteroloy 1999;116:515-520.

67 Delany BC, Innes MA, Deeks J, Wilson S, Cooner MK, Moayyedi P, Oakes R, Hobbs FD, Forman D: Initial management strategies for dyspepsia (Cochrane Review). Cochrane Database Syst Rev 2001;3:CD001961.

-68 Lassen AT, Hallas J, Schaffalitzky de Muckadell OB: Helicobacter pylori test and eradicate versus prompt endoscopy for management of dyspeptic patients: 6.7-year follow-up of a randomized trial. Gut 2004;53:1758-1763.

- 69 Lanheij RJ, van Rossum LG, Heinen N, Jansen JB: Long-term follow-up of empirical treatment or prompt endoscopy for patients with persistent dyspeptic symptoms? Eur J Gastroenterol Hepatol 2004;16:785-789.

-70 Holtmann G, Goebell H, Holtmann M, Talley NJ: Dyspepsia in healthy blood donors: pattern of symptoms and association with Helicobacter pylori. Dig Dis Sci 1994;39:1090-1098.

71 Laheij RJF, Jansen JBMJ, Van de Lisdonk EH, Severens JL, Verbeek ALM: Review article: symptoms improvement through eradiation of Helicobacter pylori in patients with non-ulcer dyspepsia. Aliment Pharmacol Ther 1996;10: 843-850.

72 Talley NJ: A critique of therapeutic trials in Helicobacter pylori-positive functional dyspepsia. Gastroenterology 1994;106:1174-1183.

-73 Gispert JP, Cruzado AI, Garcia-Gravalos R, Pajares JM: Lack of benefit of treating Helicobacter pylori infection in patients with functional dyspepsia. Randomized one-year follow-up study. Hepatogastroenterology 2004; 51:303-308.

74 Moayyedi P, Soo, S, Deeks J, Delaney B, Harris A, Innes M, Oakes R, Wilson S, Roalfe A, Bennett C, Forman D: Eradication of Helicobacter pylori for non-ulcer dyspepsia. Cochrane Database Syst Rev 2005; 1:CD002096.

-75 Abraham NS, Moayyedi P, Daniels B, Veldhuyzen van Zanten SJO: The methodological quality or trials affects estimates of treatment efficacy in functional (non-ulcer) dyspepsia. Aliment Pharmacol Ther 2004;19:631-641.

- 76 Kinoshita Y, Hashimoto T, Kawamura A, Yuki M, Amano K, Sato H, Adachi K, Sato S, Oshima N, Takashima T, Kitajima N, Abe K, Suetsugu H: Effects of famotidine, mosapride, tandospirone for treatment of functional dyspepsia. Aliment Pharmacol Ther 2005;21:37_ 41.

77 Seno H, Nakase H, Chiba T: Usefulness of famotidine in functional dyspepsia patient treatment: comparison among prokinetic, acid suppression and anti-anxiety therapies. Aliment Pharmacol Ther 2005;21:32-36.
Kato M, Watanabe M, Konishi S, Kudo M, Konno J, Meguro T, Kitamori S, Nakagawa S, Shimizu T, Takeda H, Asaka M: Randomized, double-blind, placebo-controlled crossover trial of famotidine in patients with functional dyspepsia. Aliment Pharmacol Ther 2004;21: 27-31.

79 Veldhuyzen van Zanten SJ, Chiba N, Armstrong D, Barkun A, Thomson A, Smyth S, Escobedo S, Lee J, Sinclair P: A randomized trial comparing omeprazole, ranitidine, cisapride, or placebo in Helicobacter pylori negative primary care patients with dyspepsia: the CADET-HN Study. Am J Gastroenterol 2005; 100:1477-1488.

80 Quatero AO, de Wit NJ, Lodder AC, Numans ME, Smout AJ, Hoes AW: Disturbed solidphase gastric emptying in functional dyspepsia: a meta-analysis. Dig Dis Sci 1998;43: 2028-2020.

81 Soo S, Moayyedi P, Deeks J, Delaney B, Innes M, Forman D: Pharmacological interventions for non-ulcer dyspepsia. Cochrane Database Syst Rev 2004;4:CD001960.

82 Veldhuyzen van Zanten S, Jones MJ, Verlinden M, Talley NJ: Efficacy of cisapride and domperidone in functional (nonulcer) dyspepsia: a meta-analysis. Am J Gastroenterol 2001; 96:689-696.

83 Degen L, Matinger D, Merz M, Apppel-Dingemanse S, Osborne S, Luchinger S, Bertold R, Maecke $\mathrm{H}$, Beglinger C: Tegaserod, a 5-HT partial agonist, accelerates gastric emptying and gastrointestinal transit in healthy male subjects. Aliment Pharmacol Ther 2001;15: 1745-1751.

84 Tack J, Delia T, Ligozio G, Sue S, Lefkowitz M, Vandeplasse G: A phase II placebo controlled randomized trial with tegaserod in functional dyspepsia patient with normal gastric emptying (abstract). Gastroenterology 2002;122:A154.

85 Otaka M, Jin M, Odashima M, Matsuhasi T, Wada I, Horikawa Y, Komatsu K, Ohba R, Oyake J, Hatakeyama N, Watanabe S: New strategy of therapy for functional dyspepsia using famotidine, mosapride and amitriptyline. Aliment Pharmacol Ther 2005;21:S42-S46.

86 Shenoy KT, Veenasree, Leena KB: Efficacy and tolerability of itopride hydrochloride in patients with non-ulcer dyspepsia. J Indian Med Assoc 2003;101:387-388.

87 Sawant P, Das HS, Desai N, Kalokhe S, Patil S: Comparative evaluation of the efficacy and tolerability of itopride hydrochloride and domperidone in patients with non-ulcer dyspepsia. J Assoc Physicians India 2004;52:626-628.

88 Distrutti E, Fiorucci S, Hauer SK, Pensi MO, Vanasia M, Morelli A: Effect of acute and chronic leosupiride administration on gastric tone and perception in functional dyspepsia. Aliment Pharmacol Ther 2002;16:613-622.

89 Mearin F, Rodrigo L, Perez-Mota A, Balboa A, Jimenez I, Sebastian JJ, Paton C: Levosulpiride and cisparide in the treatment of dysmotility-like functional dyspepsia: a randomized, double-masked trial. Clin Gastroenterol Hepatol 2004;2:301-308.
90 Mertz H, Fass R, Kodner A, Yan-Go F, Fullerton S, Mayer EA: Effect of amitryptiline on symptoms, sleep and visceral perception in patients with functional dyspepsia. Am J Gastroenterol 1998;93:160-165.

-91 Jackson JL, O'Malley PG, Tomkins G, Balden E, Santoro J, Kroenke K: Treatment of functional gastrointestinal disorders with anti-depressant medications: A meta-analysis. Am J Med 2000;108:65-72.

-92 Wu CY, Chou LT, Chang CS, Wong PG, Chen GH: Effect of fluoxetine on symptoms and gastric dysrhythmia in patients with functional dyspepsia. Hepatogastroenterology 2003;50:278-283.

$\$ 93$ Talley NJ, Van Zanten SV, Saez LR, Dukes G, Perschy T, Heath M, Kleodis C, Mangel AW: A dose-ranging, placebo-controlled, randomized trial of alosetron in patients with functional dyspepsia. Aliment Pharmacol Ther 2001;15:525-537.

94 Thumshirn M, Camilleri M, Cho MG, Zinsmeister AR: Modulation of gastric sensory and motor functions by nitrergic and $\alpha_{2}$-adrenergic agents. Gastroenterology 1999;116: 573-585.

\$95 Bortolotti, M, Coccia G, Grossi G, Miglioli M: The treatment of functional dyspepsia with red pepper. Aliment Pharmacol Ther 2002;16:1075-1082.

96 Gundermann KJ, Godehardt E, Ulbrich M: Efficacy of a herbal preparation in patients with functional dyspepsia: a meta-analysis of double-blind, randomized, clinical trials. Adv Ther 2003;20:43-49.

97 Holtmann G, Adam B, Haag S, Collet W, Grunewald E, Windeck T: Efficacy of artichoke leaf extract in the treatment of patients with functional dyspepsia: a six-week placebo-controlled, double-blind, multicentre trial. Aliment Pharmacol Ther 2003;18:1099_ 1105.

98 Marakis G, Walker AF, Middleton RW, Booth JC, Wright J, Pike DJ: Artichoke leaf extract reduces mild dyspepsia in an open study. Phytomedicine 2002;9:694-699.

-99 Poitras MR, Verrier P, So C, Paquet S, Bouin M, Poitras P: Group counseling psychotherapy for patients with functional gastrointestinal disorders: development of new measures for symptom severity and quality of life. Dig Dis Sci 2002;47:1297-1307.

100 Soo S, Forman D, Delaney BC, Moayyedi P: A systematic review of psychological therapies for nonulcer dyspepsia. Am J Gastroenterol 2004;99:1817-1822.

101 Hamilton J, Guthrie E, Creed F, Thompson D, Tomenson B, Bennett R, Moriarty K, Stephens W, Liston R: A randomized controlled trial of psychotherapy in patients with chronic functional dyspepsia. Gastroenterology 2000;119:661-669.

102 Calvert EL, Hughton LA, Cooper P, Whorwell PJ: Hypnotherapy is effective in longterm treatment of functional dyspepsia (abstract). Gastroenterology 2001;120:A115. 
103 Hamilton J, Guthrie E, Creed F, Thompson D, Tomenson B, Bennett R, Muriarty K, Liston R: A randomized controlled trial of psychotherapy in patients with chronic functional dyspepsia. Gastroenterology 2000;119: 661-669.

-104 Holtmann G, Kutscher SU, Haag S, Langkafel M, Heuft G, Neufang-Hueber J, Goebell H, Senf W, Talley NJ: Clinical presentation and personality factors are predictors of the response to treatment in patients with functional dyspepsia; a randomized, doubleblind, placebo-controlled crossover study. Dig Dis Sci 2004;49:672-279.

105 Soykan I, Sivri B, Sarosiek, I, Kierran B, McCallum RW: Demography, clinical characteristics, psychological profiles, treatment, and long-term follow-up of patients with gastroparesis. Dig Dis Sci 1998;43:2398-2404.

-106 Fontana RJ, Barnett JL: Jejunostomy tube placement in refractory diabetic gastroparesis: a retrospective review. Am J Gastroenterol 1996;91:2174-2178.

107 Lu CL, Shidler N, Chen JDZ: Enhanced postprandial gastric myoelectrical activity after moderate-intensity exercise. Am J Gastroenterol 2000;95:425-431.

108 Quigley EMM, Hasler W, Parkman HP: AGA technical review on nausea and vomiting. Gastroenterology 2001;120:263-286.

109 Muth ER, Jokerst M, Stern RM, Kock KL: Effects of dimenhydramine on gastric tachyarrhythmia and symptoms of vection-induced motion sickness. Aviat Space Environ Med 1995;66:1041-1045.

-110 Longstreth GF, Malagelada JR, Kelly KA: Metoclopramide stimulation of gastric motility and emptying in diabetic gastroparesis. Ann Intern Med 1977;86:195-196.

-111 Janssens J, Peeters TL, Vantrappen G, Tack J, Urbain JL, De Roo M, Muls E, Bouillon R: Improvement of gastric emptying in diabetic gastroparesis by erythromycin. N Engl J Med 1990;322:1028-1031.

- 112 Erbas T, Varoglu E, Erbas B, Tastakin G, Akalin S: Comparison of metoclopramide and erythromycin in the treatment of diabetic gastroparesis. Diabetes Care 1993;16: 1511-1514.

-113 Richards RD, Davenport K, McCallum RW: The treatment of idiopathic and diabetic gastroparesis with acute intravenous and chronic oral erythromycin. Am J Gastroenterol 1993;88:203-207.

- 114 Mozwecz H, Pavel D, Pitrak D, Orellana P, Schlesinger PK, Layden TJ: Erythromycin stearate as prokinetic agent in postvagotomy gastroparesis. Dig Dis Sci 1990;35:902-905.

-115 Ramirez B, Eaker EY, Drane WE, Hocking MP, Sninsky CA: Erythromycin enhances gastric emptying in patients with gastroparesis after vagotomy and antrectomy. Dig Dis Sci 1994;39:2295-2300.

-116 Maganti K, Onyemere K, Jones MP: Oral erythromycin and symptomatic relief of gastroparesis: as systematic review. Am J Gastroenterol 2003;98;2:259-263.
117 Patterson D, Abell T, Rothstein R, Koch K, Barnett J: A double-blind multicenter comparison of domperidone and metoclopramide in the treatment of diabetic patients with symptoms of gastroparesis. Am J Gastroenterol 1999;94:1230-1234.

118 Silvers D, Kipnes M, Broadstone V, Patterson D, Quigley EM, McCallum R, Leidy NK, Farup C, Liu Y, Joslyn A: Domperidone in the management of symptoms of diabetic gastroparesis: efficacy, tolerability, and quality of life outcomes in a multicenter controlled trial. Clin Ther 1998;20:438-453.

119 Dumitrascu DL, Weinbeck M: Domperidone versus metoclopramide in the treatment of diabetic gastroparesis. Am J Gastroenterol 2000;95:316-317.

120 Crowell MD, Mathis C, Schettler VA, Yunus T, Lacy BE: The effects of tegaserod a $5-\mathrm{HT}_{4}$ receptor agonist on gastric emptying in a murine model of diabetes mellitus. Neurogastroenterol Motil 2005;17:1-6.

- 121 Tougas G, Chen Y, Luo D, Salter J, D’Elia T, Earnest DL: Tegaserod improves gastric emptying in patients with gastroparesis and dyspeptic symptoms. Gastroenterology 2003; 124:A54.

122 Degen L, Matzinger D, Merz M, Appel-Dingemanse S, Osborne S, Luchinger S, Bertold $\mathrm{R}$, Maecke $\mathrm{H}$, Beglinger C: Tegaserod a 5- $\mathrm{HT}_{4}$ receptor partial agonist, accelerates gastric emptying and gastrointestinal transit in healthy male subjects. Aliment Pharmacol Ther 2001;15:1745-1751.

123 Banh HL, MacLean C, Topp T, Hall R: The use of tegaserod in critically ill patients with impaired gastric motility. Clin Pharmacol Therap 2005;77:583-586.

124 JI SW, Park HJ, Cho JS, Lim JH, Lee SI: Investigation into the effects of mosapride on motility of guinea pig stomach, ileum and colon. Yonsei Med J 2003;44:653-664.

125 Tsubouchi T, Saito T, Mizutani F, Yamauchi T, Iwanaga Y: Stimulatory action of itopride hydrochloride on colonic motor activity in vitro and in vivo. J Pharmacol Exp Ther 2003; 306:787-793.

126 Asakawa H, Hayashi I, Fukui T, Tokunaga K: Effect of mosapride on glycemic control and gastric emptying in type 2 diabetes mellitus patients with gastropathy. Diabetes Res Clin Practice 2003;61:175-182.

127 Ueno N, Inui A, Asakawa A, Takao F, Komatsu Y, Kotani K, Nishimura R, Kasuga M: Mosapride, a 5- $\mathrm{HT}_{4}$ receptor agnosit improves insulin sensitivity and glycemic control in patient $\mathrm{s}$ with type 2 diabetes mellitus. Diabetologia 2002;45:792-797.

128 Mansi C, Borro P, Giacomini M, Biagini R, Mele MR, Pandolfo N, Savarino V: Comparative effects of levosulpiride and cisapride on gastric emptying and symptoms in patients with functional dyspepsia and gastroparesis. Aliment Pharmacol Ther 2000;14:561-569.
129 Schwizer W, Borovicka J, Kunz P, Fraser R, Kreiss C, D'Amato M, Crelier G, Boesiger P, Fried M: Role of cholecystokinin in the regulation of liquid gastric emptying and gastric motility in humans: studies with the CCK antagonist loxiglumide. Gut 1997;41:500504.

130 Iwanaga Y, Miyashita N, Saito T, Morikawa $\mathrm{K}$, Itoh Z: Gastroprokinetic effect of a new benzamide derivative itopride and its action mechanisms on conscious dogs. Jpn J Pharmacol 1996;71:129-137.

131 Clouse RE: Antidepressants for functional gastrointestinal syndromes. Dig Dis Sci 1994; 39:2352-2363.

132 Sawhney MS, Prakash C, Lustman PJ, Clouse RE: Tricyclic antidepressants for persistent or recurrent vomiting in diabetic patients (abstract). Gastroenterology 2001;120:A243.

133 Gonlachanvit S, Chen YH, Hasler WL, Sun WM, Owyang C: Ginger reduces hyperglycemia-evoked gastric dysrhythmias in healthy humans: possible role for endogenous prostaglandins. J Pharmacol Exp Ther 2003;307; 1098-1103.

134 Wang L: Clinical observation on acupuncture treatment in 35 cases of diabetic gastroparesis. J Tradit Chin Med 2004;24:163-165.

135 Dundee JW, Ghaly RG, Bill KM, Chestnutt WN, Fitzpatrick KTJ, Lynas AG: Effect of stimulation of the P6 antiemetic point on postoperative nausea and vomiting. Br J Anaesth 1989;63:612-618.

136 Lin X, Liang J, Ren J, Mu F, Zhang M, Chen JD: Electrical stimulation of acupuncture points enhances gastric myoelectrical activity in humans. Am J Gastroenterol 1997;92: 1527-1530.

137 Lacy BE, Crowell MD, Schettler-Duncan A, Mathis C, Pasricha PJ: The treatment of diabetic gastroparesis with botulinum toxin injection of the pylorus. Diabetes Care 2004;27: 2341-2347.

138 Miller LS, Szych GA, Kantor SB, Bromer MQ, Knight LC, Maurer AH, Fisher RS, Parkman HP: Treatment of idiopathic gastroparesis with injection of botulinum toxin into the pyloric sphincter muscle. Am J Gastroenterol 2002;97:1653-1660.

139 Jones MP, Maganti K: A systematic review of surgical therapy for gastroparesis. Am J Gastroenterol 2003;98:2122-2129.

140 Watkins PJ, Buxton-Thomas MS, Howard ER: Long-term outcome after gastrectomy for intractable diabetic gastroparesis. Diabet Med 2003;20:58-63.

141 Abell TL, Van Cutsem E, Abrahamsson H, Huizinga JD, Konturek JW, Galmiche JP, Voeller G, Filez L, Everts B, Waterfall WE, DomschkeW, Bruley des Varannes S, Familoni BO, Bourgeois IM, Janssens J, Tougas G: Gastric electrical stimulation in intractable symptomatic gastroparesis. Digestion 2002; 66:204-212. 
142 Abell T, McCallum R, Hocking M, Koch K, 154 Sandler RS: Epidemiology of irritable bowel Abrahamsson H, LeBlanc I, Lindberg G, Konturek J, Nowak T, Quigley EM, Tougas G, Starkebaum W: Gastric electrical stimulation for medically refractory gastroparesis. Gastroenterology 2003;125:421-428.

143 Abell T, Lou J, Tabbaa M, Batista O, Malinowski S, Al-Juburi A: Gastric stimulation for gastroparesis improves nutritional parameters at short, intermediate, and long-term follow-up. J Parenter Enteral Nutr 2003;27: 277-281.

144 Van der Voort IR, Becker JC, Dietl KH, Konturek JW, Domschke W, Pohle T: Gastric electrical stimulation results in improved metabolic control in diabetic patients suffering from gastroparesis. Exp Clin Endocrinol Diabetes 2005;113:38-42.

145 Cutts TF, Luo J, Starkebaum W, Rashed H, Abell TL: Is gastric electrical stimulation superior to standard pharmacologic therapy in improving GI symptoms, healthcare resources and long-term health care benefits? Neurogastroenterol Motil 2005;17:35-43.

146 Rosemore J, Lacy BE: Chronic intestinal pseudo-obstruction; in Bayless TM, Diehl AM (eds): Advanced Therapy in Gastroenterology and Liver Disease, ed 5. Hamilton, Decker, 2005.

$\checkmark 147$ DeGiorgio R, Sarnelli G, Corinaldesi R, Stanghellini V: Advances in our understanding of the pathology of chronic intestinal pseudo-obstruction. Gut 2004;53:15491552.

- 148 Emmanuel AV, Shand AG, Kamm MA: Erythromycin for the treatment of chronic intestinal pseudo-obstruction: description of six cases with a positive response. Aliment Pharmacol Ther 2004; 19:687-694.

149 Ponec RJ, Saunders MD, Kimmey MB: Neostigmine for the treatment of acute colonic pseudo-obstruction. N Engl J Med 1999;341: 137-141.

150 Calvet X, Martinez JM, Martinez M: Repeated neostigmine dosage as palliative treatment for chronic colonic pseudo-obstruction in a patient with autonomic paraneoplastic neuropathy. Am J Gastroenterol 2003;98:708709.

- 151 Masetti M, Di Benedetto F, Cautero N, Stanghellini V, De Giorgio R, Lauro A, Begliomini B, Siniscalchi A, Pironi L, Cogliandro R, Pinna AD: Intestinal transplantation for chronic intestinal pseudo-obstruction in adult patients. Am J Transplant 2004;4:826829.

152 Loinaz C, Mittal N, Kato T, Miller B, Rodriguez M, Tzakis A: Multivisceral transplantation for pediatric intestinal pseudo-obstruction: single center's experience of 16 cases. Transplant Proc 2004;36:312-313.

153 Drossman DA, Corazzi E, Talley NJ, Thompson WG, Whitehead WE: Rome II. The Functional Gastrointestinal Disorders. Diagnosis, Pathophysiology and Treatment: A Multinational Consensus, ed 2. McLean/VA, Degnon Associates, 2000. syndrome in the United States. Gastroenterology 1990;99:409-415.

155 Floch MH: Use of diet and probiotic therapy in the irritable bowel syndrome: analysis of the literature. J Clin Gastroenterol 2005;39: S243-S246.

156 Quartero AO, Meinche-Schmidt B, Muris J, Rubin G, de Wit N: Bulking agents, antispasmodic and antidepressant medication for the treatment of irritable bowel syndrome. Cochrane Database Syst Rev 2005:CD003460.

157 Lesbros-Pantoflickova D, Michetti P, Fried M, Begliner C, Blum AL: Meta-analysis: The treatment of irritable bowel syndrome. Aliment Pharmacol Ther 2004;10:1253-1269.

158 Muller-Lissner S, Fumagalli I, Bardhan KD, et al: Tegaserod, a 5-HT 4 receptor partial agonist, relieves symptoms in irritable bowel syndrome patients with abdominal pain, bloating, constipation. Aliment Pharmacol Ther 2001;15:1655-1666.

159 Fried M, Beglinger C, Bobalj NG, Minor N, Coello N, Michetti P: Tegaserod is safe, well tolerated and effective in the treatment of patients with non-diarrhea irritable bowel syndrome. Eur J Gastroenterol Hepatol 2005; 17 : 421-427.

160 Camilleri M, McKinzie S, Fox J, Foxx-Orenstein A, Burton D, Thomforde G, Baxter K, Zinsmeister AR: Effect of renzapride on transit in constipation-predominant irritable bowel syndrome. Clin Gastroenterol Hepatol 2004;2:895-904.

161 Read M, Read NW, Barber DC, Duthie HL: Effects of loperamide on anal sphincter function in patients complaining of chronic diarrhea with fecal incontinence and urgency. Dig Dis Sci 1982;27:807-814.

162 Mertz H: Psychotherapeutics and serotonin agonists and antagonists. J Clin Gastroenterol 2005;39:S247-S250.

163 Lembo AJ, Olden KW, Ameen VZ, Gordon SL, Heath AT, Carter EG: Effect of alosetron on bowel urgency and global symptoms in women with severe, diarrhea-predominant irritable bowel syndrome: analysis of two controlled trials. Clin Gasteroenterol Hepatol 2004;2:675-682.

164 Lacy BE, De Lee R: Irritable bowel syndrome: a syndrome in evolution. J Clin Gastroenterol 2005;39:S230-S242.

165 Higgins PDR, Davis KJ, Laine L: The epidemiology of ischemic colitis. Aliment Pharmacol Ther 2004;19:729-738.

166 Poynard T, Naveau S, Mory B, Chaput JC: Meta-analysis of smooth muscle relaxers in the treatment of irritable bowel syndrome. Aliment Pharmacol Ther 1994;8:499-510.

167 Morgan V, Pickens D, Gautman S, Kessler R, Mertz H: Amitriptyline reduces rectal painrelated activation of the anterior cingulate cortex in patients with irritable bowel syndrome. Gut 2005;54:569-573.

168 Drossman DA, Camilleri M, Mayer EA, Whitehead WE: AGA Technical review on irritable bowel syndrome. Gastroenterology 2002;123:2108-2131.
169 Kuiken SD, Tygat GN, Boeckxstaens GE: The selective serotonin reuptake inhibitor fluoxetine does not change rectal sensitivity and symptoms in patients with irritable bowel syndrome: a double-blind, randomized, placebo-controlled study. Clin Gastroenterol Hepatol 2003;1:219-228.

170 Tabas G, Beaves M, Wang J, Friday P, Mardini H, Arnold G: Paroxetine to treat irritable bowel syndrome not responding to high-fiber diet: a double blind, placebo-controlled trial. Am J Gastroenterol 2004;99:914-920.

171 Kennedy T, Jones R, Darnley S, Seed P, Wessely S, Chalder T: Cognitive behaviour therapy in addition to antispasmodic treatment of irritable bowel syndrome in primary care: randomized controlled trial. BMJ 2005;431435.

172 Lackner JM, Mesmer C, Morley S, Dowzer C. Hamilton S: Psychological treatments for irritable bowel syndrome: a systematic review and meta-analysis. J Consult Clin Psychol 2004;72:1100-1113.

173 Crowell MD, Jones MP, Harris LA, Dineen TN, Schettler VA, Olden KW: Antidepressants in the treatment of irritable bowel syndrome and visceral pain syndromes. Curr Opin Investig Drugs 2004;5:736-742.

174 Saggioro A: Probiotics in the treatment of irritable bowel syndrome. J Clin Gastroenterol 2004;38:S104-S106.

175 O'Mahoney L, McCarthy J, Kelly P, Hurley G, Luo F, Chen K, O'Sullivan GC, Kiely B, Collins JK, Shananhan F, Quigley EM: Lactobacillus and Bifidobacterium in irritable bowel syndrome: symptom responses and relationship to cytokine profiles. Gastroenterology 2005;128:541-551.

176 Delvaux M, Beck A, Jacob J, Bouzamondo H, Weber FT, Frexinos J: Effect of asimadoline, a $\kappa$-opioid agonists, on pain induced by colonic distention in patients with irritable bowel syndrome. Aliment Pharmacol Ther 2004;20:237-246.

177 Bundy R, Walker AF, Middleton RW, Booth $\mathrm{J}$ : Tumeric extract may improve irritable bowel symptomology in otherwise healthy adults: a pilot study. J Altern Complement Med 2004;10:1015-1018.

178 Xiao WB, Liu YL: Rectal hypersensitivity reduced by acupoint TENS in patients with diarrhea-predominant irritable bowel syndrome: a pilot study. Dig Dis Sci $2004 ; 49$ : 312-319.

179 Xing J, Larive B, Mekhail N, Soffer E: Transcutaneous electrical acustimulation can reduce visceral perception in patients with irritable bowel syndrome: a pilot study. Altern Ther Health Med 2004;10:38-42.

180 Tan G, Hammond DC, Joseph G: Hypnosis and irritable bowel syndrome: a review of efficacy and mechanism of action. Am J Clin Hypn 2005;47:161-178.

181 Gonsalkorale WM, Whorwell PJ: Hypnotherapy in the treatment of irritable bowel syndrome. Eur J Gastroenterol Hepatol 2005; 17 : $15-20$. 
182 Rao SS: Constipation: evaluation and treatment. Gastroenterol Clin North Am 2003; 323:659-683.

183 Lembo A, Camilleri M: Chronic constipation. N Engl J Med 2003;349:1360-1368.

184 Higgins PD, Johanson JF: Epidemiology of constipation in North America: a systematic review. Am J Gastroenterol 2004;99:750759.

185 Brandt LJ, Prather CM, Quigley EM, Schiller LR, Schoenfeld P, Talley NJ: Systematic review on the management of chronic constipation in North America. Am J Gastroenterol 2005; 100:S5-S21.

- 186 Dennison C, Prasad M, Lloyd A, Bhattacharyya SK, Dhawan R, Coyne K: The healthrelated quality of life and economic burden in constipation. Pharmacoeconomics 2005; 23:461-476.

187 Bouhnik Y, Neut C, Raskine L, Michel C, Riottot M, Andrieux C, Guillemot F, Dyard F, Flourie B: Prospective, randomized, parallel-group trial to evaluate the effects of lactulose and polyethylene glycol-4000 on colonic flora in chronic idiopathic constipation. Aliment Pharmacol Ther 2004;19:889-899.

188 Cash BD, Lacy BE: Systematic review: prescription medications for adults with constipation. Submitted.

189 Cleveland MV, Flavin DP, Ruben RA, Epstein RM, Clark GE: New polyethylene glycol laxative for treatment of constipation in adults: a randomized, double-blind, placebocontrolled study. South Med J 2001;94:478481.

190 DiPalma JA, DeRidder PH, Orlando RC, Kolts BE, Cleveland MB: A randomized, placebo-controlled, multi-center study of the safety and efficacy of a new polyethylene glycol laxative. Am J Gastroenterol 2000;95: 446-450.
191 Corazziari E, Badiali D, Bazzocchi G, Bassotti G, Roselli P, Mastropaolo G, Luca MG, Galeazzi R, Peruzzi E: Long-term efficacy, safety, and tolerability of low daily doses of isosmotic polyethylene glycol electrolyte balanced solution (PMF-100) in the treatment of functional chronic constipation. Gut 2000; 46:522-526.

192 Kamm MA, Muller-Lissner S, Talley NJ, Tack J, Boeckxstaens G, Minushkin ON, Kalinin A, Dzieniszewski J, Haeck P, Fordham F, Hugot-Cournez S, Nault B: Tegaserod for the treatment of chronic constipation: a randomized, double-blind, placebo-controlled multinational study. Am J Gastroenterol 2005; 100:362-372.

193 Johanson JF, Wald A, Tougas G, Chey WD, Novick JS, Lembo AJ, Fordham F, Guella M, Nault B: A randomized, double-blind, controlled trial. Clin Gastroenterol Hepatol 2004;2:796-805.

194 Bouras EP, Camilleri M, Burton DD, Thomforde G, McKinzie S, Zinsmeister AR: Prucalopride accelerates gastrointestinal and colonic transit in patients with constipation without a rectal evacuation disorder. Gastroenterology 2001;120:354-360.

195 Emmanuel AV, Roy AJ, Nicholls TJ, Kamm MA: Prucalopride, a systemic enterokinetic, for the treatment of constipation. Aliment Pharmacol Ther 2002;16:1347-1356.

196 Coremans G, Kerstens R, DePauw M, Stevens $M$ : Prucalopride is effective in patients with severe chronic constipation in whom laxatives fail to provide adequate relief. Results of a double-blind, placebo-controlled clinical trial. Digestion 2003;67:82-89.

197 Sloots CE, Poen AC, Kerstens R, Stevens M, De Pauw M, Van Oene JC, Meuwissen SG, Felt-Bersma RJ: Effects of prucalopride on colonic transit, anorectal function and bowel habits in patients with chronic constipation. Aliment Pharmacol Ther 2002;16:759-767.
98 Parkman HP, Rao SS, Reynolds JC, Schiller LR, Wald A, Miner PB, Lembo AJ, Gordon JM, Drossman DA, Waltzman L, Stambler N, Cedarbaum JM: Functional Constipation Study Investigators. Neurotrophin-3 improves functional constipation. Am J Gastroenterol 2003;98:1338-1347.

199 Johanson J, Gargano M, Holland PC, Patchen M, Ueno R: Phase III efficacy and safety of Lubiprostone, a novel chloride channel activator, for the treatment of constipation. Oral presentation, Digestive Disease Week, New Orleans, 2004.

200 Johanson JF, Gargano MA, Holland PC, Patchen ML, Ueno R: Initial and sustained effects of lubiprostone, a chloride channel-2 (ClC-2) activator for the treatment of constipation: data from a 4-week phase III study. Am J Gastroenterol 2005; 100:S324.

201 Liu Z, Sakakibara R, Odaka T, Uchiyama T, Uchiyama T, Yamamoto T, Ito T, Asahina M, Yamaguchi K, Yamaguchi T, Hattori T: Mosapride citrate, a novel 5- $\mathrm{HT}_{4}$ agonist and partial 5- $\mathrm{HT}_{3}$ antagonist, ameliorates constipation in parkinsonian patients. Mov Disord 2005;20:680-686.

202 Camilleri M: Alvimopan, a selective peripherally acting $\mu$-opioid antagonist. Neurogastroenterol Motil 2005;17:157-165.

203 Garnett W, Kelleher DL, Hickmott F, et al Alvimopan shortens whole bowel transit time in adults with chronic constipation. Gastroenterology 2004;126:A643.

204 Chiarioni G, Saladini L, Whitehead WE: Biofeedback benefits only patients with outlet dysfunction, not patients with isolated slow transit constipation. Gastroenterology 2005 129:86-97.

205 Palsson OS, Heymen S, Whitehead WE: Biofeedback treatment for functional anorectal disorders: a comprehensive efficacy review. Appl Psychophysiol Biofeedback 2004;29: 153-174. 